\title{
PROFIL PIODERMA PADA ORANG DEWASA DI POLIKLINIK KULIT DAN KELAMIN RSUP PROF. DR. R. D. KANDOU MANADO TAHUN 2012
}

\author{
${ }^{1}$ Fahriah \\ ${ }^{2}$ Herry E. J. Pandaleke \\ ${ }^{2}$ Grace M. Kapantow \\ ${ }^{1}$ Kandidat Skripsi Fakultas Kedokteran Universtas Sam Ratulangi Manado \\ ${ }^{2}$ Bagian Ilmu Penyakit Kulit dan Kelamin Fakultas Kedokteran \\ Univeristas Sam Ratulanngi Manado \\ Email: fahriah_11_055@rocketmail.com
}

\begin{abstract}
Pyoderma is the most common skin-bacterial disease caused by infection. The main causes of pyoderma are staphylococcus aureus and streptococcus sp. Pyoderma can occur among females or males of any ages. Generally, pyoderma is influenced by nutrient state, skin integrity, immunologic condition, and environmental condition inter alia heat, humidity, as well as poor sanitation and hygiene. This study aimed to obtain the profil of pyoderma at Dermato-venereology Department, Prof. Dr. R. D. Kandou General Hospital Manado from January to December 2012. This was a retrospective study using data of pyoderma patient medical records Prof. Dr. R. D. Kandou Hospital Manado within January-December 2012. The results showed that the occurence of pyoderma in 2012 was 1.09\% (44 cases), most were females 52.3\% (23 cases), and aged 45-46 years 52,3\% (23 cases). Cellulitis is a type of pyoderma which occured $52.3 \%$ (23 cases). Clindamycin is a systemic antibiotic which was used the most, 65.9\% (29 cases), and topical antibiotic which was mostly used was fucidic acid 31.8\% (14 cases). Conclusion: Cellulitis was the most common case found, in females were more than in males, aged 45-64 years old. Clindamycin was the mostly used systemic antibiotics, while the topical one was fucidic acid.
\end{abstract}

Keywords: skin infected disease, adult, pyoderma

\begin{abstract}
Abstrak: Pioderma adalah penyakit infeksi bakterial kulit yang paling sering ditemukan. Penyebab utama pioderma ialah bakteri staphylococcus aureus maupun streptococcus sp. Pioderma dapat menyerang laki-laki maupun perempuan pada semua usia. Terjadinya pioderma umumnya dipengaruhi oleh gizi, integritas kulit, kondisi imunologis, serta faktor lingkungan seperti panas, kelembaban, kurangnya sanitasi dan higieni. Penelitian ini bertujuan untuk mengetahui profil pasien pioderma pada orang dewasa di poliklinik RSUP Prof. Dr. D. Kandou Manado periode Januari - Desember 2012. Penelitian ini bersifat studi retrospektif menggunakan data catatan medik penderita pioderma yang datang ke poliklinik kulit dan kelamin RSUP Prof. Dr. R. D. Kandou Manado bulan Januari - Desember 2012. Hasil penelitian menunjukkan insiden pioderma tahun 2012 1,09\% (44 kasus). Distribusi menurut jenis kelamin terbanyak pada perempuan yaitu 52,3\% (23 kasus). Menurut kelompok umur terbanyak pada umur 45-64 tahun yaitu 52,3\% (23 kasus). Jenis pioderma terbanyak ialah selulitis 52,3\% (23 kasus). Distribusi berdasarkan penggunaan antibiotik sistemik yang terbanyak digunakan ialah klindamisin sebanyak 65,8\% (29 kasus), dan atibiotik topikal terbanyak digunakan ialah asam fusidat 31,8\% (14 kasus). Simpulan: Selulitis merupakan kelompok kasus terbanyak yang ditemukan, perempuan lebih banyak daripada laki-laki, kelompok umur yang paling banyak terkena ialah 45-64 tahun, antibiotik sistemik yang terbanyak digunakan ialah klindamisin dan untuk penggunaan antibiotik topikal terbayak ialah asam fusidat.
\end{abstract}

Kata kunci: penyakit kulit infeksi, dewasa, pioderma 
Penyakit infekki kulit bakterial merupakan masalah kesehatan masyarakat, ${ }^{1}$ dimana infeksi bakterial pada kulit yang paling sering ditemui adalah pioderma. ${ }^{2}$ Pioderma termasuk sepuluh penyakit terbanyak di Indonesia bahkan menempati urutan ke empat setelah ISPA, hipertensi primer dan demam. $^{3}$ Pioderma adalah penyakit kulit yang disebabkan oleh bakteri pembentuk pion. Penyebab utama adalah bakteri Staphylococcus aureus dan Streptococcus sp.

Terjadinya pioderma umumnya dipengaruhi oleh gizi, hygieni, iklim, kedaan atau penyakit yang mendasari. ${ }^{4}$ Manifestasi klinis infeksi bakteri pada pioderma sangat bervariasi, sesuai dengan bakteri penyebabnya, bagian tubuh yang diserang, dan keadaan imunologik penderita. ${ }^{5}$

Dibagian Ilmu Penyakit Kulit dan Kelamin Fakultas Kedokteran Universitas Indonesia, insiden pioderma menduduki peringkat ketiga. ${ }^{1}$ Penyakit ini berhubungan erat dengan keadaan sosial ekonomi.Tidak ada ras tertentu yang cenderung terkena pioderma. Pioderma dapat menyerang lakilaki maupun perempuan pada semua usia. ${ }^{1}$

Prevalensi pioderma dibeberapa negara, seperti di Brazil, Ethiopia, Taiwan, dan lain-lain adalah 0,2-35 \%, sedangkan prevalensi pioderma di Indonesia adalah $1,4 \%$ pada dewasa dan $0,2 \%$ pada anak. ${ }^{6}$

Data insiden pioderma di Poliklinik Kulit dan Kelamin RS Sanglah Denpasar selama periode januari 2006 - Desember 2008 menunjukkan 6,5\% (287 kasus), 6,23\% (267 kasus), 4,5\% (175 kasus). ${ }^{3}$

Data profil pioderma pada dewasa khususnya di Manado belum pernah dilaporkan. Oleh karena itu peneliti tertarik meneliti insiden pioderma pada dewasa di Poliklinik Kulit dan Kelamin RSUP Prof. R. D. Kandou Manado yang dikorelasikan dengan umur, jenis kelamin, pekerjaan, dan terapi.

\section{METODE PENELITIAN}

Penelitian dilakukan secara retrospektif dan data dikumpulkan dari buku register dan catatan medik pasien yang datang di poliklinik kulit dan kelamin RSUP Prof. Dr. R. D. Kandou Manado periode JanuariDesember 2012.

Hasil pencatatan dikelompokkan berdasarkan jumlah kunjungan penderita pioderma selama Januari-Desember 2012, jenis kelamin, umur, jenis pioderma, pekerjaan dan terapi. Hasil penelitian disajikan dalam bentuk tabel.

\section{HASIL PENELITIAN}

Penderita yang datang berobat ke Poliklinik Kulit dan Kelamin RSUP Prof. Dr. R. D. Kandou Manado selama periode Januari hingga Desember 2012 sebanyak 44 orang (Tabel 1).

Tabel 1.Distribusi Pasien Penyakit Kulit Pioderma

\begin{tabular}{ccc}
\hline Tahun & $\begin{array}{c}\text { Total kunjungan } \\
\text { pada } \\
\text { Poliklinik }\end{array}$ & $\begin{array}{c}\text { Total penderita } \\
\text { pioderma } \\
(\%)\end{array}$ \\
\hline 2012 & 4023 & $44(1,09)$ \\
\hline
\end{tabular}

Berdasarkan distribusi Penderita Infeksi Pioderma pada Dewasa, diketahui bahwa yang paling sering terkena ialah perempuan sejumlah 23 orang (52,3\%).

Tabel 2. Distribusi Penderita Infeksi Pioderma pada Dewasa menurut Jenis Kelamin di Poliklinik Kulit dan Kelamin RSUP Prof. Dr. R. D. Kandou Manado periode 2012

\begin{tabular}{lcc}
\hline $\begin{array}{c}\text { Jenis } \\
\text { Kelamin }\end{array}$ & Jumlah & \% \\
\hline Laki-laki & 21 & 47,7 \\
Perempuan & 23 & 52,3 \\
\hline \multicolumn{1}{c}{ Jumlah } & 44 & 100 \\
\hline
\end{tabular}

Berdasarkan tabel 3 jumlah penderita pioderma terbanyak pada umur 45-64 tahun, yakni sebanyak 23 penderita (52,3\%).

Pada tabel 4 diatas didapatkan bahwa selulitis merupakan jenis pioderma yang terbanyak yaitu sebanyak 23 pasien (52,3\%). 
Tabel 3. Distribusi Penderita Infeksi Pioderma pada Dewasa menurut Umur di Poliklinik Kulit dan Kelamin RSUP Prof. Dr. R. D. Kandou Manado periode 2012

\begin{tabular}{ccc}
\hline Umur & Jumlah & $\%$ \\
\hline $15-24$ tahun & 2 & 4,5 \\
$25-44$ tahun & 11 & 25,0 \\
$45-64$ tahun & 23 & 52,3 \\
$\geq 65$ tahun & 8 & 18,2 \\
\hline Total & 44 & 100 \\
\hline
\end{tabular}

Tabel 4. Distribusi Jenis Pioderma di Poli Klinik Kulit dan Kelamin RSUP Prof. Dr. R. D.Kandou Manado Periode 2012

\begin{tabular}{lcc}
\hline Diagnosis & Jumlah & $\mathbf{\%}$ \\
\hline Impetigo Krustosa & 1 & 2,3 \\
Impetigo Bulosa & 1 & 2,3 \\
Furunkel & 7 & 15,8 \\
Karbunkel & 1 & 2,3 \\
Folikulitis & 8 & 18,2 \\
Selulitis & 23 & 52,3 \\
Erysipelas & 2 & 4,5 \\
Ektima & 1 & 2,3 \\
\hline Jumlah & 44 & 100 \\
\hline
\end{tabular}

Pada tabel 5 klindamisin merupakan antibiotik sistemik paling banyak digunakan dengan jumlah 29 (65,8\%).

Pada tabel 6 didapatkan asam fusidat merupakan antibiotik topikal paling

Berdasarkan data yang ada, jumlah penderita pioderma dewasa periode 2012 sebanyak 44 pasien $1,09 \%$ dari semua kunjungan pada ploklinik Kulit dan Kelamin RSUP Prof. DR. R. D. Kandou Manado.

Selulitis merupakan jenis pioderma paling banyak pada orang dewasa sebanyak 23 pasien (52,3\%), diikuti folikulitis 8 pasien (18,2\%), dan furunkel 7 pasien (15,9\%).Selulitis dapat terjadi di semua usia, tersering pada usia di bawah 3 tahun dan usia dekade keempat dan kelima. $^{7}$ Semakin bertambahnya usia, insiden selulitis juga semakin meningkat. ${ }^{8}$ Hal ini kemungkinan disebabkan oleh trauma pada kulit (abrasi) dan juga adanya penyakit menahun. Abrasi kulit pada usia lanjut banyak digunakan dengan jumlah 14 (31,8\%).

Tabel 5. Distribusi penggunaan Antibiotik Sistemik Pada Penderita Infeksi Pioderma Dewasa Di Poliklinik Kulit dan Kelamin RSUP Porf. Dr. R D Kandou Manado

\begin{tabular}{lcl}
\hline Antibiotik & Jumlah & $\mathbf{\%}$ \\
\hline Klindamisin & 29 & 65,8 \\
Amoxicillin & 1 & 2,3 \\
Cefadroxil & 5 & 11,4 \\
Ciprofloxacin & 1 & 2,3 \\
Tidak mengguna- & 8 & 18,2 \\
kan antibiotik* & & \\
\hline
\end{tabular}

Ket.: *mendapatkan terapi antibiotik topikal

Tabel 6. Distribusi Penggunaan Antibiotik Topikal Pada Penderita Infeksi Pioderma Dewasa di Poliklinik Kulit dan Kelamin RSUP Prof. Dr. R. D. Kandou Manado

\begin{tabular}{lcc}
\hline Antibiotik & Jumlah & $\mathbf{\%}$ \\
\hline Asam Fusidat & 14 & 31,8 \\
Mupirocin & 5 & 11,4 \\
Gentamicin & 2 & 4,5 \\
Neomicin, bacitracin & 1 & 2,3 \\
powder & & \\
Tidak menggunakan & 22 & 50,0 \\
antibiotik* & 44 & 100 \\
\hline Jumlah & Ket.: *mendapatkan terapi antibiotik sistemik
\end{tabular}

sering terjadi dikarenakan adanya perubahan struktur kulit yang semakin menipis dan rapuh. Abrasi kulit ini dapat menyebabkan timbulnya kolonisasi bakteri yang akan memicu invasi bakteri sehingga memudahkan terjadinya infeksi. Pada usia lanjut juga sering mengalami penyakit menahun (misalnya, diabetes). Penyakit menahun ini akan menurunkan sistem imun dalam tubuh yang akan menyebabkan mudahnya terkena infeksi. Pada penelitian ini, ditemukan bahwa jenis pioderma yang paling jarang terjadi yaitu impetigo. Impetigo dapat terjadi pada orang dewasa, tetapi lebih sering terjadi pada bayi, anakanak, di usia prasekolah dan sekolah kemungkinan karena kulit anak yang relatif lebih tipis dan ikatan antar sel yang masih 
longgar serta imunitas kulit terhadap imfeksi masih lemah. ${ }^{9}$

Data distribusi menurut jenis kelamin memperlihatkan perempuan lebih banyak menderita pioderma dibandingkan laki-laki (1,1:1), namun tidak menunjukkan perbedaan yang mencolok. Hasil ini berbeda dengan yang dilaporkan Laksmi dkk. Di RS Sanglah Denpasar (2006-2008) yakni pasien laki-laki lebih banyak dibandingkan perempuan. ${ }^{3}$

Data distribusi menurut usia menunjukkan pada usia 45-64 tahun yang terbanyak terinfeksi pioderma. Hasil penelitian ini tidak serupa dengan hasil data profil pioderma di Poliklinik Kulit dan Kelamin RS Sanglah Denpasar yakni paling tinggi terkena pioderma pada kelompok usia 25-44 tahun. ${ }^{3}$ Banyaknya penderita pioderma pada kelompok usia 4564 tahun kemungkinan disebabkan oleh imobilitas yang akan menyebabkan perubahan sistem integumen pada usia lanjut, seperti terjadinya atrofi epidermis, kelenjar keringat, dan folikel rambut serta berubahnya pigmentasi dengan akibat penipisan kulit, folikel, dan berurangnya lemak subkutan yang menyebabkan berkurangnya bantalan kulit sehingga daya tahan terhadap tekanan dan perubahan suhu menjadi berkurang. Akibatnya mudah terjadi decubitus, hipotermia atau hipertermia. Penipisan kulit juga dapat menyebabkan kulit mudah terluka dan terjadi infeksi kulit. ${ }^{10}$

Data distribusi menurut pekerjaan menunjukkan jenis pekerjaan dari 44 pasien, hanya diperoleh data mengenai pekerjaan sebanyak 14 pasien. Data pekerjaan 30 pasien lainnya tidak tercantum di buku register maupun di buku rekam medik. Dari hasil data tidak dapat disimpulkan jenis pekerjaan yang paling banyak yang terkena pioderma karena tidak ditemukannya status pasien.

Dari hasil penelitian didapatkan antibiotik terbanyak yang digunakan untuk terapi sistemik ialah klindamisin (65,9\%). Meskipun diketahui bahwa penisilin merupakan drug of choice dalam pengobatan pioderma namun penisilin sudah tidak lagi digunakan karena bakteri penyebab pioderma memiliki resisten yang tinggi terhadap penisilin sehingga klindamisin digunakan sebagai obat pilihan selain penisilin. Klindamisin bekerja dengan cara menekan produksi toksin yang dihasilkan oleh staphylococcus aureus dan streptococcus grup A sehingga efektif dalam pengobatan pioderma. ${ }^{11}$ Selain klindamisin, terdapat obat pilihan lainnya untuk terapi pioderma antara lain eritromisin, sefaleksin, nafcilin, dan doksisiklin. Eritromisin digunakan sebagai obat alternatif unutk pasien yang mengalami alergi terhadap penisilin. Eritromisin menghambat pertumbuhan bakteri dengan cara memblokir disolasi peptidyl t-RNA dari ribisom. Sefaleksin adalah generasi pertama sefalosporin, yang menghambat pertumbuhan bakteri dengan menghambat sintesis dinding sel bakteri. Seperti eritromisin, sefaleksin dan diclixacilin dapat digunakan sebagai pilihan obat untuk pengobatan pioderma bagi pasien yang mempunyai alergi dan resisten terhadap penisilin. ${ }^{12}$

Untuk terapi topikal antibiotik yang paling banyak digunakan adalah asam fusidat 14 (31,8\%), mupirocin 5 (11,4\%). Asam fusidat krim diindikasikan untuk lesi kulit primer dan sekunder yang disebabkan oleh infeksi streptococcus dan atau staphylococcus yang bekerja dengan cara menghambat sintesis protein bakteri.

\section{SIMPULAN}

Selulitis adalah kelompok kasus terbanyak yang ditemukan, perempuan lebih banyak daripada laki-laki, kelompok umur yang paling banyak terkena adalah usia 45-64 tahun, dan antibiotik sistemik yang paling banyak digunakan adalah klindamisin dan untuk penggunaan antibiotik topikal yang terbayak adalah asam fusidat.

\section{SARAN}

1. Selama penelitian penulis mengalami beberapa kendala seperti : kurang lengkapnya data pasien di catatan rekam medik dan buku register. Oleh 
karena itu itu diharapkan agar buku register pasien diisi dengan lengkap dan status pasien di bagian instalasi rekam medik dijaga dengan baik agar data yang diperoleh lebih akurat.

2. Perlu dilakukan penilitian lebih lanjut tentang hubungan pekerjaan dengan pioderma.

3. Perlu dilakukan penilitian angka prevalensi pioderma untuk tahun-tahun berikutnya, agar dapat diketahui angka prevalensi pada setiap tahunnya.

\section{UCAPAN TERIMA KASIH}

Ucapan terima kasih disampaikan kepada dr. Renate Tamara Kandou, SpKK (K), FINSDV dan dr. Nur Djannah Jane Niode, SpKK, FINSDV. Juga kepada semua pihak, baik secara langsung maupun tidak langsung, yang telah menumbuhkan ide dan gagasan bagi penulis.

\section{DAFTAR PUSTAKA}

1. Djuanda A. Pioderma. In: Juanda A, Hamzah M, Aisah S, editors. Ilmu penyakit kulit dan kelamin (Edisi-6). Jakarta: Badan Penerbit FK UI,2 011: 57-63.

2. Marwali H. Impetigo bulosa dalam ilmu penyakit kulit dan kelamin (1st ed). Jakarta: Hipokrates Publisher, 2000.

3. Laksmi Dewi BAAA, Dhana Saputra IPK, Rusyati LM, Bratiartha MD, Adiguna MS. Profil Pioderma di Poliklinik Klinik dan Kelamin RS Sanglah Denpasar Periode Januari 2006 - Desember 2008. Perdoski.

4. Pandeleke HEJ. Penyakit kulit bakteri (Pioderma). In: Pandeleke HEJ, Warouw WFTh, editors. Bahan ajar dermatologi umum. Manado: Bagian Ilmu Penyakit Kulit dan Kelamin Fakultas Kedokteran UNSRAT: 2006; p.97-108.

5. Sjahrial. Infeksi Bakteri Stafilokok dan
Streptoko. In: Harahap M, editor. Ilmu penyakit kulit. Jakarta: Hipokrates, 2000; p.46-59.

6. WHO. Epidemiology and Management of Common Skin Diseases in Children in Developing Countries. 2005. [cited 2014 September 25]; Available from: http://whqlibdoc.who.int/hq/2005/WH O_FCH_CAH_05.12_eng.pdf

7. Craft N, Lee PK, Zipoli MT, Weinberg AN, Swartz MN, Johnson RA. Fitzpatrick's Dermatology in General Medicine (7th ed). New York: McGraw Hill Medical. 2008

8. Ellis SSM, Van Orman ER, Hatch BE, Jones SS, Gren LH, Hegmann KT, Lyon JL. Cellulitis incidence in a defined population. 2005. [cited 12 Dec 2014] Available from : http://www.ncbi.nlm.nih.gov/pmc/articl es/PMC2870381

9. Aisah S. Epidemiologi penyakit infeksi serta peran sawar kulit pada infeksi mikroorganisme pada kulit bayi dan anak. Dalam: Aisah S, Lestari T, Kurniati DD, Elandari, editor. Infeksi kulit bayi dan anak. Jakarta: Balai Penerbit FKUI, 2003; hal. 1-16.

10. Martono HH. Aspek Fisiologik dan Patologik Akibat Proses Menua. In: Martono HH, Pranarka K (eds). Buku Ajar Boedhi Darmojo Geriatri (Ilmu Kesehatan Usia Lanjut) Edisi ke-4. Jakarta: Balai penerbit Fakultas Kedokteran Universitas Indonesia, 2009; p. 56-74.

11. Guidelines on the management of cellulitis in adults. 2005. [cited 2014 Des 16]; Available from: http://www.acutemed.co.uk/docs/Cellul itis\%20guidelines,\%20CREST,\%2005. pdf.

12. Baorto EP. Staphylococcus aureus infection. Steele RW, editor. Update [cited 18 Mar 2015] Available from : http://emedicine.medscape.com. 